\title{
Serum uric acid in type 2 diabetics
}

\author{
Bassam E . Hanna, Jamal M. Hammed \\ Department of Biochemistry, Nineveh College of Medicine, University of Mosul.
}

(Ann. Coll. Med. Mosul 2008; 34(1): 69-75).

Received: $21^{\text {st }}$ Nov 2007; Accepted: $21^{\text {st }}$ May 2008.

\begin{abstract}
:
Aims: To compare the level of serum uric acid (UA) in type 2 diabetics with a control group and to demonstrate its relation with other risk factors as age , BMI, duration of diabetes, blood glucose and total cholesterol level.

Methods: The study was conducted in Al-Wafa Diabetic Clinic in Mosul during the period from February to May 2007 as a case-control study. A 39 patients of both sexes with type 2 diabetes with a mean \pm SD age of $51.5 \pm 11.1$ years, and 20 healthy subjects of both sexes with a mean \pm SD age of $46.5 \pm 15.5$ years as a control group. The concentrations of fasting serum glucose, total cholesterol and UA was determined; BMI was calculated.

Results: BMI, fasting serum glucose, UA and total cholesterol concentrations are significantly higher $(\mathrm{P}<0.001,0.01,0.01$ respectively) in type 2 diabetics compared to the control group with a positive correlation $(r=0.605, P<0.005)$ between serum UA and the duration of diabetes.

Conclusions: Because serum UA concentration is significantly higher in type 2 diabetics independent on other factors and as it predicts the occurrence of ischemic heart diseases, stroke and even renal disease in these patients; therefore, its measurement is recommended. Since it positively correlated with the duration of diabetes, therefore, the longer the history of diabetes was, the more frequent measurement should be done.
\end{abstract}

الخلاصة

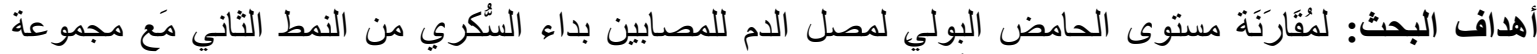

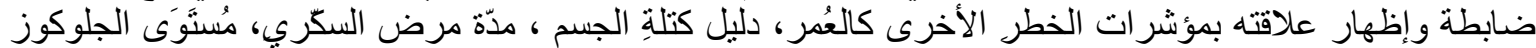

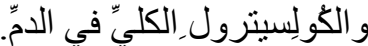

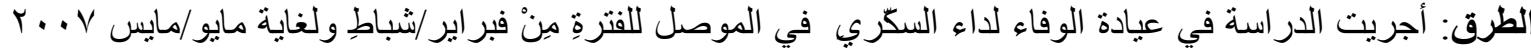

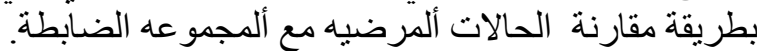

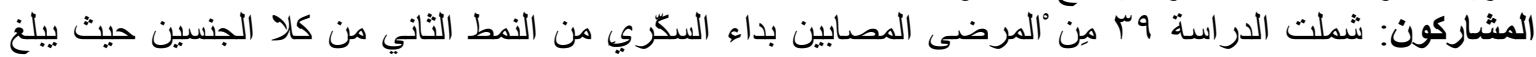

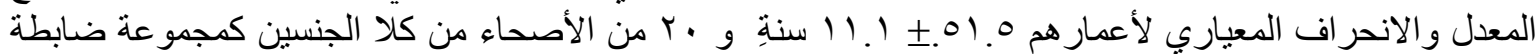

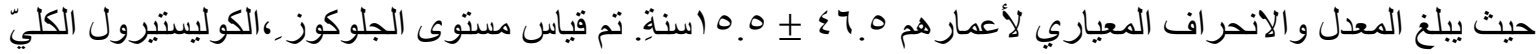

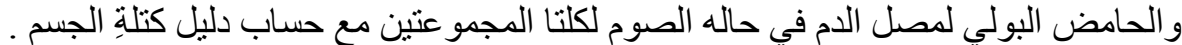

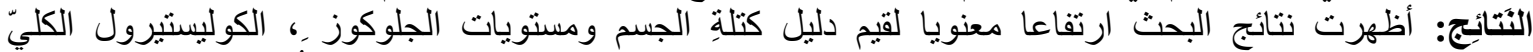

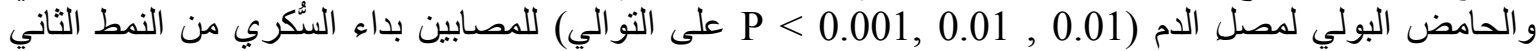

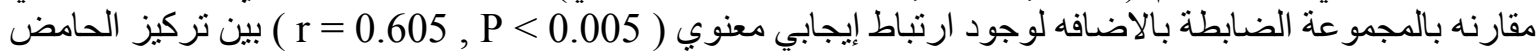

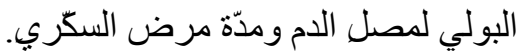

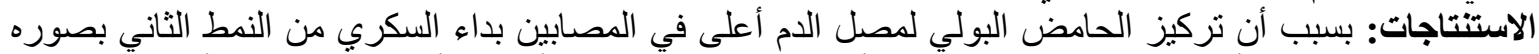

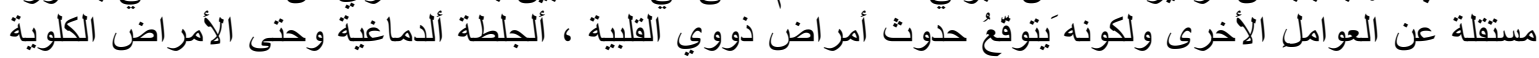

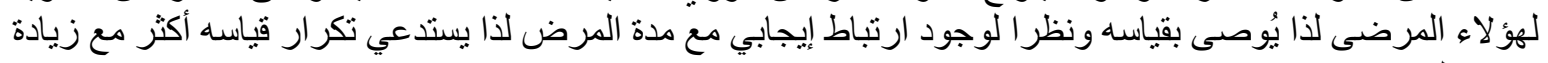

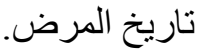


$\mathrm{H}$

umans convert adenosine and guanosine into $U A^{(1)}$. In mammals other than higher primates, uricase converts UA to the water-soluble allantoin. However, since humans lack uricase, the end product of purine catabolism is UA ${ }^{(1)}$.

Different studies have indicated that hyperuricemia predicts the development of ischemic heart disease in non-diabetic subjects ${ }^{(2-6)}$, this applies also to the patients with type 2 diabetes ${ }^{(7)}$. Even "asymptomatic hyperuricemia" have also demonstrated a remarkable association with hypertension, obesity, metabolic syndrome, kidney disease, and cardiovascular disease ${ }^{(8-13)}$. And lowering UA in patients with renal disease and asymptomatic hyperuricemia resulted in less progression of their renal problem ${ }^{(14,}$ 15)

Recent studies in humans found that elevated serum UA predicts the development of hyperinsulinemia (16), obesity ${ }^{(17,18)}$, type 2 diabetes ${ }^{(16,19)}$, in addition to the development of stroke in middle-aged patients with type 2 diabetes independently of other cardiovascular risk factors ${ }^{(20)}$.

The aim of this study is to compare the UA concentration in patients with type 2 diabetes with a control group in Mosul city and its relation with other risk factors as age, Body Mass Index (BMI), duration of diabetes, blood glucose and total cholesterol level in those diabetic patients.

\section{Patients and methods}

This study was conducted during the period from February to May 2007, the subjects enrolled in this study were divided into two groups (group I and II).

Group I composed of 20 apparently healthy subjects (11males and 9 females), their ages ranged from (29-77) years with a mean \pm SD of $46.5 \pm 15.5$ years.

Group II composed of 39 patients (17 males and 22 females) with type 2 diabetes was diagnosed by clinical history and laboratory investigations who were attending Al-Wafa Diabetic Clinic in Mosul. Their ages ranged from (26-73) years with a mean \pm SD of $51.5 \pm 11.1$ years. They have no any evidence of renal, cardiovascular or stroke attacks. None of the control and patients had a history of any cause that may affect their serum UA concentration.

A complete record of history was obtained, including name, age, sex, duration of diabetes, diet and drugs; measurement of height $(\mathrm{Ht})$ and weight (Wt) was done for all subjects enrolled in the study. Fasting blood samples were obtained from the patients and controls then blood samples were centrifuged at $3000 \mathrm{rpm}$ for 15 minutes. Estimation of serum glucose, total cholesterol and UA was done within one hour of sample collection in the clinical chemistry laboratory of the Department of Biochemistry, Nineveh College of Medicine, by the enzymatic colorimetric methods using glucose oxidase peroxidase $^{(21)}$, cholesterol oxidase ${ }^{(22)}$ and uricase methods ${ }^{(23)}$ respectively. The results were evaluated by statistical methods including the mean $(\bar{X})$, standard deviation (SD), range (minimum- 
maximum), Linear regression analysis (Pearson correlation coefficient $r$ ), paired and unpaired student's t-test $(24,25,26)$ to evaluate the relation between different parameters in group I and II. Differences between observations were considered not significant at $\mathrm{p}>0.05$. BMl was calculated by dividing $\mathrm{Wt} / \mathrm{Ht}^{(2,27)}$.

\section{Results}

There is no significant difference $(P>0.05)$ in the age between group I and II (Table 1).
Fasting serum glucose, UA and total cholesterol concentrations are significantly higher in group II than group I $(P<0.001$, $0.01,0.01$ respectively, table 1 ).

BMI in group II was significantly higher than group I $(P<0.001$, table 1$)$.

There is positive correlation $(r=0.605, p$ $<0.005$ ) between serum UA concentration and the duration of diabetes in group II (Fig:1) while there is no significant correlations with age, BMI, fasting serum glucose and serum total cholesterol level.

Table 1 : Comparison between different parameters of both groups.

(Values are presented as mean \pm SD)

\begin{tabular}{||c|c|c|c|}
\hline \multicolumn{1}{|c|}{ Parameter } & $\begin{array}{c}\text { Croup I } \\
(\text { Control) } \\
\mathrm{n}=20\end{array}$ & $\begin{array}{c}\text { Group II } \\
\text { (Type 2 diabetics) } \\
\mathrm{n}=39\end{array}$ & P-Value \\
\hline \hline Age (years) & $46.5 \pm 15.5$ & $51.5 \pm 11.1$ & $\mathrm{NS}$ \\
\hline BMI (Kg/m ${ }^{2}$ ) & $26.37 \pm 1.79$ & $30.11 \pm 4.41$ & $\mathrm{P}<0.001$ \\
\hline Glucose $(\mathrm{mmol} / \mathrm{L})$ & $4.36 \pm 0.37$ & $8.79 \pm 2.96$ & $\mathrm{P}<0.001$ \\
\hline Uric Acid $(\mu \mathrm{mol} / \mathrm{L})$ & $0.20 \pm 0.07$ & $0.28 \pm 0.09$ & $\mathrm{P}<0.01$ \\
\hline $\begin{array}{c}\text { Total Cholesterol } \\
(\mathrm{mmol} / \mathrm{L})\end{array}$ & $4.21 \pm 0.68$ & $4.96 \pm 1.06$ & $\mathrm{P}<0.01$ \\
\hline
\end{tabular}

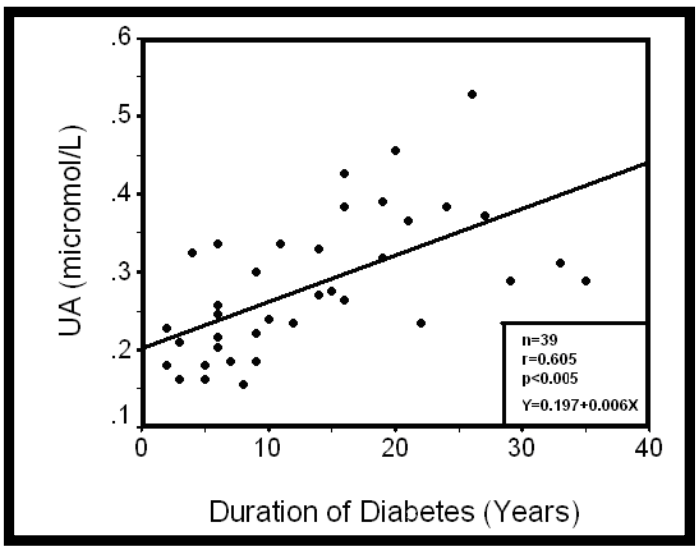

Fig:1 Correlation between serum uric acid and duration of diabetes in group II. 


\section{Discussion}

Measurement of serum UA is important in type 2 diabetics as it predicts the development of ischemic heart disease, stroke and even renal diseases in these patients independent of other risk factors $(7-13,20)$.

In this study it was found that fasting serum UA concentration was significantly higher in type 2 diabetics than in control subjects.

Evidently group II patients have other significantly higher risk factors for ischemic heart diseases in comparison with the control subjects such as (serum total cholesterol, blood glucose and $\mathrm{BMI}$ ) and even, according to the National Center for Health Statistics, only $5.13 \%$ of group II patients with BMI within acceptable range while $61.54 \%$ are overweight , $30.77 \%$ are obese and $2.56 \%$ are morbidity obese. However, in this study there is no any significant correlation between serum UA and these risk factors. This finding is in agreement with other studies that showed serum UA is an independent risk factor in diabetics not dependent on age, BMI or plasma glucose concentration ${ }^{(7-13,20,28)}$.

Facchini et al ${ }^{(29)}$, explain the cause of high UA in elevated insulin resistance on the basis reported that urinary UA clearance decreased in proportion to increases in insulin resistance in normal volunteers. They attributed that compensatory hyperinsulinemia in subjects with insulin resistance possibly causing decreased renal excretion of UA in association with increased sodium reabsorption.

On the other hand, it was reported that UA reduces endothelial nitric oxide bioavailability ${ }^{(30)}$, which is essential for insulinstimulated glucose uptake in skeletal muscle (31).

Different studies showed controversy about the role of UA on vascular complications. Some concluded that UA is one of the major endogenous water-soluble antioxidants of the body (32) and there is an accumulating evidence that increased oxidative stress is closely related to diabetes and its vascular complications ${ }^{(33)}$. Thus, high circulating UA levels may be an indicator that the body is trying to protect itself from the deleterious effects of free radicals by increasing the products of endogenous antioxidants, e.g., UA. In addition, UA prevents oxidative modification of endothelial enzymes and preserves the ability of endothelium to mediate vascular dilatation in the face of oxidative stress ${ }^{(32)}$. In contrast, other studies concluded that UA may have a direct role in the atherosclerotic process, because human atherosclerotic plaque contains more UA than in the arteries of the control subjects ${ }^{(34)}$. Because inflammation is one of the features of atherosclerosis ${ }^{(35)}$, UA crystals may induce inflammatory responses that are reduced by lipoproteins which have an ability to bind UA crystals (36). Hyperuricemia via purine metabolism may also promote thrombus formation. ${ }^{(37,38)}$ and the elevations of UA above $4 \mathrm{mg} / \mathrm{dl}$ should be considered a "red flag" in those patients at risk for 
cardiovascular disease and should alert the clinician to strive to utilize a global risk reduction program in a team effort to reduce the complications of the atherogenic process resulting in the morbid - mortal outcomes of cardiovascular disease ${ }^{(13)}$.

In conclusions; as UA concentration is significantly higher in diabetics and as different studies proved that high UA predicts the development of ischemic heart disease, stroke and even renal diseases independent on other factors, therefore, its measurement is recommended. As serum UA is positively correlated with the duration of diabetes, therefore, the longer the history of diabetes was, the more frequent serum UA measurement should be done.

\section{References}

1. Robert K, Darly K, Peter A, Victor W. Harper's illustrated biochemistry. $26^{\text {th }}$ ed . McGraw-Hill Companies 2003 ;299.

2. Bengtsson C, Lapidus L, Stendahl C, Waldenström J. Hyperuricaemia and risk of cardiovascular disease and overall death: a 12-year follow-up of participants in the population study of women in Gothenburg, Sweden. Acta Med Scand 1988;224:549555.

3. Levine W, Dyer AR, Shekelle RB, Schoenberger JA, Stamler J. Serum uric acid and 11.5-year mortality of middle-aged women: findings of the Chicago Heart Association Detection Project in Industry. Clin Epidemiol 1989;42:257-267.

4. Persky VW, Dyer AR, Idris-Soven E, Stamler J, Shekelle RB, Schoenberger JA, et al. Uric acid: a risk factor for coronary heart disease? Circulation $1979 ; 59$ : 969-977.
5. Abbott RD, Brand FN, Kannel WB, Castelli WP. Gout and coronary heart disease. J Clin Epidemiol 1988;41:237242.

6. Freedman DS, Williamson DF, Gunter EW, Byers T. Relation of serum uric acid to mortality ischemic heart disease:. Am J Epidemiol 1995;141:637-644

7. Rathmann W, Hauner $H$, Dannehl K, Gries FA. Association of elevated serum uric acid with coronary heart disease in diabetes mellitus. Diabet Med 1993;19:159-166.

8. Johnson RJ, Feig DI, Herrera-Acosta J, Kang DH. Resurrection of uric acid as a causal risk factor in essential hypertension. Hypertension 2005; 45:1820.

9. Association between serum uric acid and some cardiovascular risk factors in a Chinese population. Postgraduate Medical Journal 1994 ; 70: 486-491

10.Iseki K, Oshiro S, Tozawa M, Iseki C, Ikemiya Y, Takishita S. Significance of hyperuricemia on the early detection of renal failure in a cohort of screened subjects. The Japanese society of hypertension, Hypertension Research 2001; 24:691-697.

11.Domrongkitchaiporn $\mathrm{S}$, Sritara $\mathrm{P}$, Kitiyakara C, Stitchantrakul W, Krittaphol $\mathrm{V}$, Lolekha $\mathrm{P}$, et al. Risk factors for development of decreased kidney function in a southeast Asian population: a 12-year cohort study. J Am Soc Nephrol 2005; 16:791-799.

12. Iseki K, Ikemiya Y, Inoue T, Iseki C, Kinjo K, Takishita S. Significance of 
hyperuricemia as a risk factor for developing ESRD in a screened cohort. Am J Kidney Dis 2004 ; 44:642-650.

13. Hayden, Melvin, Tyagi, Suresh .Uric acid: A new look at an old risk marker for cardiovascular disease, metabolic syndrome, and type 2 diabetes mellitus: The urate redox shuttle. Nutrition\& Metabolism $2004 ; 1: 10$.

14.Siu YP, Leung KT, Tong MK, Kwan TH. Use of allopurinol in slowing the progression of renal disease through its ability to lower serum uric acid level. Am J Kidney Dis 2006; 47:51-59.

15. Neal DA, Tom BD, Gimson AE, Gibbs $P$, Alexander GJ. Hyperuricemia, gout, and renal function after liver transplantation. Transplantation 2001; 72:1689-1691.

16. Nakanishi N, Okamoto $M$, Yoshida $H$, Matsuo Y, Suzuki K, Tatara K. Serum uric acid and risk for development of hypertension and impaired fasting glucose or Type II diabetes in Japanese male office workers. Eur $\mathrm{J}$ Epidemiol 2003; 18:523-530.

17. Masuo K, Kawaquchi $H$, Mikami $H$, Oqihara T, Tuck ML. Serum uric acid and plasma norepinephrine concentrations predict subsequent weight gain and blood pressure elevation. Hypertension 2003; 42:474-480.

18. Messerli FH, Frolich ED, Dreslinski GR, Suarez DH, Aristimuno GG. Serum uric acid in essential hypertension: an indicator of renal vascular involvement. Ann Intern Med1980; 93: 817-821.

19.Taniguchi Y, Hayashi T, Tsumura K, Endo G, Fujii S, Okada K. Serum uric acid and the risk for hypertension and type 2 diabetes in Japanese men: The Osaka Health Survey. J Hypertens 2001; 19:1209-1215.

20.Seppo Lehto, Leo Niskanen, Tapani Rönnemaa, Markku Laakso. Serum uric acid is a strong predictor of stroke in patients with Non-Insulin-Dependent Diabetes Mellitus. American Heart Association,Inc. Stroke 1998;29:635-639.

21.David B. Carbohydrates. In: Tietz fundamentals of clinical chemistry ( Carls A Burtis, Edward R Ashwood, eds) . $4^{\text {th }}$ ed. Saunders com 1996 ; 362-363.

22.Evan A Stein, Gary L Myers. Lipid, apolipoprtein and lipoproteins. In: Tietz fundamentals of clinical chemistry ( Carls A Burtis, Edward R Ashwood, eds) . 4th ed. Saunders com 1996 ; 394-395.

23. Andrew Whelton, Alan J Watson, Robert C Rock. Nitrogen metabolism and renal function. In: Tietz fundamentals of clinical chemistry ( Carls A Burtis , Edward R Ashwood, eds) . 4th ed. Saunders com $1996 ; 579-580$.

24.Armitage $P$. Statistical methods in medical research. 41th printing. Oxford, London : Blackwell Scientific Publications $1974 ; 62-64$.

25.David Jones .Pharmaceutical statistics. Pharmaceutical press 2002; 94-96, 166$170,210-221,276-290,460-494,521-$ 537.

26.Armen Khachatryan ,Nikos M. Biostatistics and epidemiology .McGrawHill 1998; 20-21, 40, 55-56.

27. Garrow JS , Webster J. Quetlet's index $(\mathrm{W} / \mathrm{H} 2)$ as a measure of fatness. 
International Journal of Obesity 1985; 9: 147-153.

28. H Vuorinen-Markkola, H Yki-Jarvinen . Hyperuricemia and insulin resistance. Journal of Clinical Endocrinology \& Metabolism 1994 ; 78; 25-29.

29. Facchini F, Chen YID, Hollenbeck CB, Reaven GM. Relationship between resistance to insulin-mediated glucose uptake, urinary uric acid clearance, and plasma uric acid concentration .JAMA 1991;266:3008-3011.

30. Khosla UM, Zharikov S, Finch JL, Nakagawa $\mathrm{T}$, Roncal $\mathrm{C}, \mathrm{Mu} \mathrm{W}$, et al. Hyperuricemia induces endothelial dysfunction. Kidney Int 2005;67:17391742.

31. Roy D, Perreault M, Marrette A. Insulin stimulation of glucose uptake in skeletal muscle and adipose tissues in vivo is NO dependent. Am J Physiol 1998;274:692699.

32. Becker BF. Towards the physiological function of uric acid. Free Radic Biol Med 1993;14:615-631.

33. Baynes JW. Role of oxidative stress in the development of complications in diabetes mellitus. Diabetes 1991;40:405-412.
34. Suarna C, Dean RT, May J, Stocker R. Human atherosclerotic plaque contains both oxidized lipids and relatively large amounts of alpha-tocopherol and ascorbate. Arterioscler Thromb Vasc Biol 1995;15:1616-1624.

35. Fuster $\mathrm{V}$, Badimon L, Badimon JJ, Chesebro JH. The pathogenesis of coronary artery disease and the acute coronary syndromes. $\mathrm{N}$ Engl $\mathrm{J}$ Med 1992;326:310-318.

36. Feingold KR, Grunfeld C. Role of cytokines in including hyperlipidemia. Diabetes 1992;41(suppl 2):97-101.

37. Visy J, Le-Coz P, Chadefaux B, Fressinaud C, Woimant F, Marquet J, et al . Homocystinuria due to 5,10methylenetetrahydrofolate reductase deficiency revealed by stroke in adult siblings. Neurology 1991;41:1313-1315.

38. Kuwano K, Ikeda H, Oda T, Nakayama $\mathrm{H}$, Koga $\mathrm{Y}$, Toshima $\mathrm{H}$, et al. Xanthine oxidase mediates cyclic flow variations in a canine model of coronary arterial thrombosis. Am J Physiol 1996;270:1993-1999. 